\title{
MOTIVASI BELAJAR SISWA KELAS SMK KELAS X PADA MATA PELAJARAN PEKERJAAN DASAR TEKNIK OTOMOTIF
}

\author{
Khoeruman ${ }^{1}$, Mumu Komaro ${ }^{2}$, Ridwan A. M. Noor $^{3}$ \\ Universitas Pendidikan Indonesia \\ Jl. Dr. Setiabudhi No. 229, Bandung 40154 \\ khoeruman_0904000@yahoo.co.id
}

\begin{abstract}
ABSTRAK
Penelitian ini bertujuan untuk mengetahui motivasi belajar siswa dalam mata pelajaran pekerjaan dasat teknik otomotif kompetensi keahlian teknik otomotif. Metode penelitian yang digunakan adalah metode deskriptif dengan pendekatan kuantitatif. Sampel penelitian ini sebanyak 99 siswa kelas X. Instrumen dalam penelitian ini menggunakan angket tertutup dengan menggunakan skala Likert. Hasil dari penelitian menunjukkan bahwa motivasi belajar siswa kelas X pada mata pelajaran pekerjaan dasar teknik otomotif rata-rata 78,7\%. Sebagian besar siswa kelas X memiliki motivasi dalam belajar khususnya pada mata pelajaran pekerjaaan dasar teknik oromotif. Kesimpulan penelitian ini yaitu siswa kelas X memiliki motivasi belajar yang baik dapat memproleh nilai yang memuaskan dan di atas KKM.
\end{abstract}

Kata kunci: motivasi belajar, pekerjaan dasar teknik otomotif.

\section{PENDAHULUAN}

Perkembangan ilmu pengetahuan, teknologi dan persaingan global sangatlah pesat membawa perubahan di hampir semua aspek kehidupan, agar mampu bertahan dalam persaingan global, maka sebuah bangsa perlu untuk terus mengembangkan dan meningkatkan kuaitas sumber daya manusianya. Peningkatan kualitas sumber daya manusia merupakan kenyataan yang harus benar dilakukan secara terencana, terarah, intensif, efektif dan efisien dalam proses membanguan (Djamarah dan Zain, 2014). Salah satu upaya untuk meningkatkan kualitas SDM yaitu dengan meningkatkan kualitas sistem pendidikan. Negara Indonesia merupakan salah satu negara yang menjadikan pendidikan sebagai sarana dan prasarana yang digunakan dalam upaya peningkatan pembangunan bangsa dan negara. Peraturan Pemerintah No 32 Tahun 2013 tentang Standar Proses Pendidikan Dasar dan Menengah.

Hal ini sesuai dengan misi sekolah SMK Negeri 1 Katapang merupakan SMK yang memiliki bidang keahlian Teknik Otomotif. SMK Negeri 1 Katapang berupaya terus untuk meningkatkan keterampilan siswanya guna menciptakan lulusan yang produktif. Misi sekolah adalah menanamkan sikap peserta didik yang berwawasan mutu, keunggulan, profesionalisme berlandaskan penanaman nilai-nilai keimanan, kejujuran dan akhlak mulia.

\footnotetext{
1 Mahasiswa Departemen Pendidikan Teknik Mesin FPTK UPI

2 Dosen Departemen Pendidikan Teknik Mesin FPTK UPI

3 Dosen Departemen Pendidikan Teknik Mesin FPTK UPI
} 
Salah satu usaha untuk mewujudkan tujuan dan misi tersebut adalah meningkatkan kualitas proses pembelajaran di sekolah (Hamalik, 2014).

Keberhasilan pada dasarnya tidak mungkin dapat tercapai, tanpa didasari oleh motivasi yang tinggi dan kecendrungan untuk menguasai kondisi lingkungan yang dinyatakan lewat sikap. Motivasi belajar diberikan guru kepada siswa agar dapat mendorong siswa untuk memperoleh ilmu, penuasaan kemahiran, serta pembentukan sikap kepercayaan diri yang tinggi sehingga siswa dapat meraih prestasi yang lebih baik. Proses pendidikan dapat ditinjau dari tingkat keberhasilan belajar siswa, pada suatu pembelajaran dipengaruhi oleh berbagai faktor, baik berasal dari dalam diri sendiri (faktor intern) maupun berasal dari luar diri sendiri (faktor ekstern). Faktor yang yang berifat intern, misalnya: kecerdasan, bakat, minat, perhatian, motivasi, sikap, kesehatan jasmani, dan aktifitas belajar. Faktor ekstern, misalnya lingkungan alam, lingkungan masyarakat, lingkungan sekolah dan sarana belajar. Sedangakan faktor ekstern adalah faktor yang ada di luar individu (Slameto, 2013).

Mata pelajatan Pekerjaan Dasar Teknik Otomotif (PDTO) merupakan salah satu dari dasar aplikasi teknologi di bidang otomotif. Pada mata pelajaran PDTO berada dikelompok C2. Mata pelajaran ini merupakan dasar dari mata pelajaran produktif sebelum melangkah ke mata pelajaran produktif selanjutnya untuk di kelompok C3 yang harus di tempuh, sehingga betapa pentingnya siswa menguasi materi pada mata pelajaran PDTO.

Mata pelajaran PDTO merupakan salah satu Kompetensi Dasar yaitu membahas tentang salah satu materinya yaitu memahami semua alat ukur dimana siswa harus mempelajari mengenai pengehuan dasar pengukuran, peralatan bengkel, cara merawatnya serta keselaman kerja dan lingkungan di dalamnya. Sehingga pada saat mempelajari materi ini siswa diharapkan untuk bisa memiliki ketekunan, ketelitian, kecepatan, kompetensi menganalisis permasalahan (Sanjaya, 2008). Akan tetapi kenyataanya siswa belum memiliki motivasi yang besar sehingga berdampak pada hasil belajar yang belum optimal. Hasil belajar ini meliputi aspek kognitif (pengetahuan), aspek psikomotor (keterampilan) dan aspek efektif (sikap). Konsep pengukuran hasil belajar di sekolah ditetapkakn oleh standar ketuntasan atau keriteria ketuntasan minimum (KKM) sebesar 72. Hal ini sesuai dengan petunjuk teknis penilaian hasil belajar dengan menggunakan Kurikulum 2013, dengan menggunakan skala 0-100.

Hasil pengalaman PPL dan observasi terhadap guru pengajar untuk SKP, sampai saat ini motivasi siswa dalam pembelajaran mata pelajaran pekerjaan dasar teknik otomotif yang bersifat pasif. Hal ini dirasa kurang, siswa sulit untuk menangkap yang diberikan oleh guru sehingga proses pembelajaran pembelajaran tidak berlangsung secara efektif apabila diikuti 
dengan aktifitas siswa. Pada awal pembelajaran siswa belum mendapat motivasi dari guru sehingga siswa akan menjadi jenuh dan kurang aktif dalam mengikuti pelajaran yang diberikan (Kuswana, 2013).

Motivasi sebagai dorongan mental yang menggerakan dan mengarahkan perilaku manusia, termasuk perilaku belajar (Dimyanti dan Mudjiono, 2009). Seseorang akan berhasil dalam belajar, kalau pada dirinya ada keinginan untuk belajar. Keinginan atau dorongan inilah yang disebut motivasi, motivasi dalam hal ini meliputi dua hal, yaitu mengetahui apa yang akan dipelajari dan memahami mengapa hal tersebut patut di pelajari. Hasil observasi awal di lapangan, masih ada siswa yang kurang termotivasi dalam melaksanakan pembelajaran (Uno, 2014). Hal ini mengakibatkan siswa kurang menguasai kompetensi. Masih ditemukan tidak hanya aktivitas belajar saja yang rendah tetapi hasil belajar siswa pun juga rendah. Artinya masih banyak siswa belum kompeten. Hasil belajar peserta didik yang masih rendah, terlihat dari predikat yang di capai siswa pada level cukup. Jumlah peserta didik yang dinyatakan kompeten sebanyak 50 orang (44,6\%). Jumlah peserta didik yang belum kompeten sebanyak 62 orang $(55,4 \%)$. Ada 62 orang siswa belum kompeten, nilainya berada di atas KKM yang ditetapkan sekolah, yaitu 72 .

Banyak siswa yang belum bisa dikatakan kompeten. Salah satu upanya agar siswa dapat mengikuti proses pembelajaran aktif yaitu guru harus memotivasi yang inovatif dan disesuaikan dengan kondisi atau lingkungan belajar. Memberikan suntikan motivasi sebelum pembelajaran sangat diperlukan. Hal itu untuk mempermudah proses pembelajaran sehingga dapat mencapai hasil yang optimal berlangsung secra efektif dan efisien. Tujuan pembelajaran yang diinginkan tercapai terpenuhi dengan baik. Oleh karena itu, dalam proses pembelajaran pekerjaan dasar teknik otomotif diperlukan motivasi tinggi yang dapat mempermudah proses pembelajaran.

\section{METODE PENELITIAN}

Penelitian ini menggunakan metode penelitian deskriptif dengan pendekatan kuantitatif. Metode ini dipilih karena materi-materi mengkaji bentuk, aktivitas, karakteristik, perubahan, hubungan kesamaan dan perbedaannya dengan fenomena lain. Penelitian deskriptif tidak memberikan perlakuan, manipulasi atau pengubahan pada variabel-variabel bebas, tetapi menggambarkan suatu kondisi apa adanya. Sampel peneltian ini sebanyak 99 orang siswa kelas X. Instrumen dalam penelitian ini menggunakan angket tertutup dengan menggunakan skala Likert. 


\section{HASIL PENELITIAN}

Hasil penelitian ini akan menjabarkan mengenai deskripsi data eksplorasi motivasi belajar siswa kelas $\mathrm{X}$ pada mata pelajaran pekerjaan dasar teknik otomotif kompetensi keahlian teknik kendaraan ringan. Presentase pencapaian kebutuhan fisiologis dalam hal mempertahankan hidup mencapai 75,70\%. Merujuk pada penafsiran persentase secara kuantitas tingkat pencapaian kebutuhan fisiologis sebagian besar siswa telah tercapai. Presentase tingkat pencapaian rasa aman dalam hal kepastian keadaan dan lingkungan, mencapai 77,57\%. Dapat ditafsirkan bahwa secara kuantitas tingkat pencapaian kebutuhan rasa aman sebagian besar siswa telah tercapai. Presentase pencapaian rasa cinta dilihat dari pertalian atau hubungan dengan orang lain, mencapai $82,98 \%$. Nilai memiliki makna bahwa secara kuantitas tingkat pencapaian kebutuhan rasa cinta sebagian besar telah tercapai. Presentase pencapaian penghargaan terhadap diri atau rasa berguna bagi orang lain, mencapai $63,04 \%$. Merujuk pada penafsiran persentase secara kuantitas tingkat pencapaian penghargaan terhadap diri lebih dari setengahnya telah tercapai.

Presentase tingkat pencapaian aktualisasi diri atau pengembangan diri, mencapai $79 \%$. Penafsiran persentase secara kuantitas tingkat pencapaian kebutuhan aktualisasi diri sebagian besar siswa telah tercapai. Presentase pencapaian memuaskan rasa ingin tahu, mencapai $82,27 \%$. Penafsiran persentase secara kuantitas tingkat pencapaian memuaskan rasa ingin tahu sebagian besar telah tercapai. Presentase tingkat pencapaian kebutuhan estetik atau keteraturan, mencapai $85,2 \%$. Penafsiran persentase secara kuantitas tingkat pencapaian kebutuhan estetik atau keteraturan sebagian besar telah tercapai. Persentase pencapaian kebutuhan berdasarkan aspek yang telah ditentukan, bahwa rata-rata motivasi belajar siswa kelas X pada mata pelajaran pekerjaan dasar teknik otomotif mencapai $78,76 \%$. Artinya sebagian besar siswa kelas X memiliki motivasi dalam belajar khususnya pada mata pelajaran pekerjaan dasar teknik otomotif.

\section{PEMBAHASAN}

Motivasi merupakan dorongan pada diri seseorang untuk mengarahkannya dalam bertingkah laku. Siswa akan termotivasi pada apabila sudah mengetahui tujuan atau capaian dirinya sendiri dalam mata pelajaran pekerjaan dasar teknik otomotif (Faisal, et. al., 2016). Persentase dari setiap aspek motivasi direntangkan dari 0-100\% akan terlihat hasil pengolehan data yang menggambarkan motivasi siswa terhadap mata pelajaran PDTO, sementara untuk persentase keseluruhan motivasi belajar siswa SMK Negeri 1 Katapang 
adalah memiliki motivasi sebesar $78,76 \%$ dan $21,24 \%$ siswa tidak memiliki motivasi belajar. Artinya sebagian besar siswa SMK Negeri 1 Katapang memiliki motivasi belajar, khususnya pada mata pelajaran pekerjaan dasar teknik otomotif. Melihat dari hasil tersebut, bahwa ada faktor lain yang dapat meningkatkan motivasi belajar siswa. Faktor penyebab meningkatnya motivasi belajar siswa dilihat dari indikator paling tinggi yaitu efeksi/ pertalian dengan orang lain dan kebutuhan estetik (Kuswinarko dan Kusumah, 2017).

Kondisi motivasi belajar siswa dengan cara melihat jawaban individu/siswa terhadap tiap pertanyaan angket atau kuesioner. Apabila deskripsi motivasi tiap indikator direntangkan antara 0-100\%, maka akan terlihat indikator mana yang paling dominan memiliki peranan dalam memotivasi siswa untuk melaksanakan pembelajaran (Dinata dan Kusumah, 2017). Pada Gambar 1 ditunjukkan persentase motivasi belajar tiap indikator.

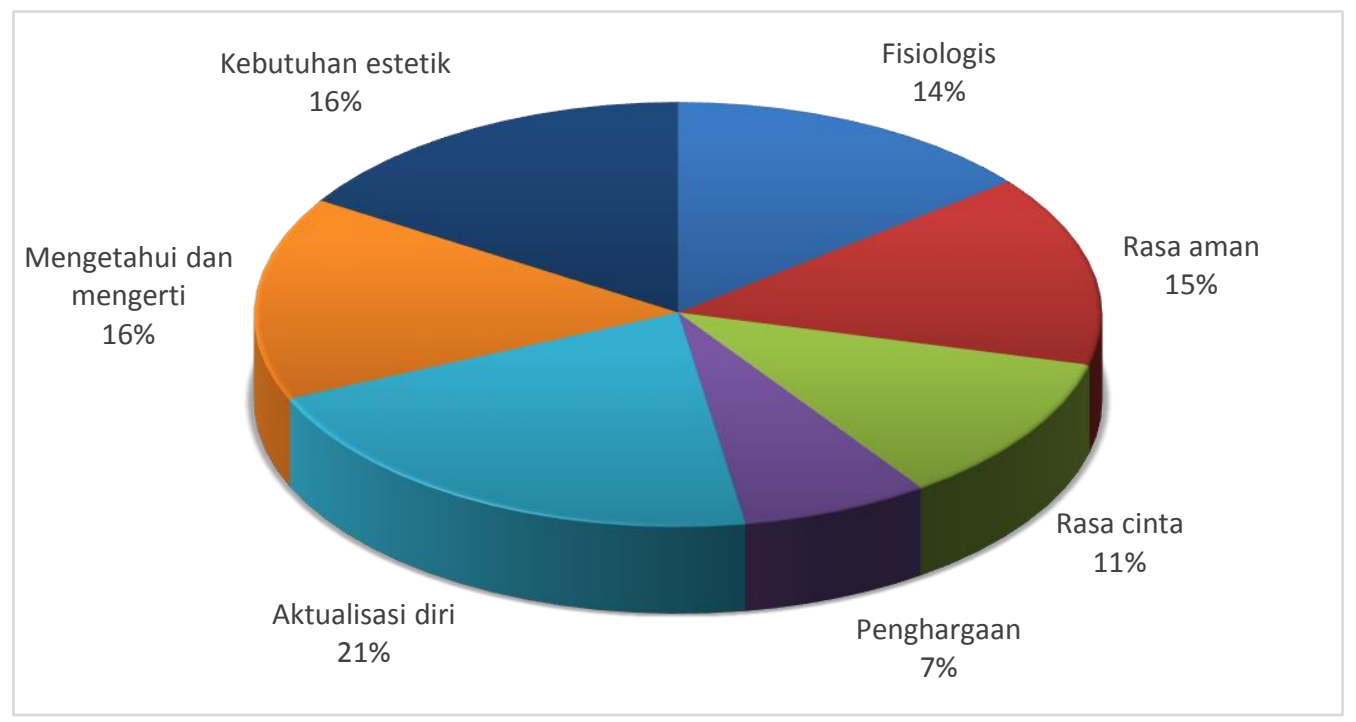

Gambar 1. Diagram persentase motivasi belajar siswa tiap indikator

Aspek aktualisasi diri memberikan sumbangan besar pada motivasi belajar siswa yaitu $21 \%$. Aspek mengetahui, mengerti dan kebutuhan estetik memiliki sumbangan sebanyak 16\% pada motivasi belajar siswa. Aspek rasa aman memberikan sumbangan sebesar 15\% dan aspek fisiologis memberikan sumbangan sebesar $14 \%$ pada motivasi belajar siswa. Siswa yang dimiliki motivasi belajar berdasarkan aspek rasa cinta sebesar 11\% dan aspek penghargaan sebesar $7 \%$.

\section{KESIMPULAN}

Kesimpulkan penelitian ini, sebagai berikut: rata-rata motivasi belajar siswa kelas $\mathrm{X}$ TKR pada mata pelajaran pekerjaan dasar teknik otomotif memiliki motivasi yang cukup 
dalam belajar. Presentase tingkat pencapaian kebutuhan fisiologis dalam hal mempertahankan hidup secara kuantitas tingkat pencapaian sebagian besar siswa telah tercapai. Presentase tingkat pencapaian rasa aman dalam hal kepastian keadaan dan lingkungan secara kuantitas tingkat pencapaian sebagian besar siswa telah tercapai, Presentase tingkat pencapaian rasa cinta dilihat dari pertalian atau hubungan dengan orang lain secara kuantitas tingkat pencapaian sebagian besar telah tercapai. Presentase tingkat pencapaian penghargaan terhadap diri atau rasa berguna bagi orang lain secara kuantitas tingkat pencapaian lebih dari setengahnya telah tercapai. Presentase tingkat pencapaian aktualisasi diri atau pengembangan diri, secara kuantitas tingkat pencapaian sebagian besar siswa telah tercapai. Presentase tingkat pencapaian memuaskan rasa ingin tahu, persentase secara kuantitas tingkat pencapaian memuaskan rasa ingin tahu sebagian besar telah tercapai. Presentase tingkat pencapaian kebutuhan estetik atau keteraturan, secara kuantitas tingkat pencapaian sebagian besar telah tercapai.

\section{REFERENSI}

Dinata, M. J., dan Kusumah, I. H. (2017). Motivasi Belajar Siswa pada Mata Pelajaran Pemeliharaan Sistem Kelistrikan Kendaraan Ringan. Journal of Mechanical Engineering Education, 4(1), 92-95.

Djamarah, S. B. dan Zain. A. (2014). Strategi Belajar Mengajar. Jakarta: Rineka Cipta.

Faisal, H. N. M., Kuswana, W. S., dan Permana, T. (2016). Eksplorasi Motivasi Belajar Siswa Pada Mata Pelajaran Pemeliharaan Sistem Kelistrikan Kendaraan Ringan. Journal of Mechanical Engineering Education, 3(2),167-173

Hamalik, O. (2014). Kurikulum dan Pembelajaran. Jakarta: PT. Bumi Aksara

Kuswana, W. S. (2013). Filsafat Pendidikan Teknologi, Vokasi dan Kejuruan. Bandung: Alfabeta.

Kuswinarko, M., dan Kusumah, I. H. (2017). Eksplorasi Motivasi Belajar Siswa SMK dalam Mengikuti Mata Pelajaran Pekerjaan Dasar Teknik Otomotif. Journal of Mechanical Engineering Education, 4(1), 96-100.

Sanjaya, W. (2008). Kurikulum dan Pembelajaran. Jakarta: Kencana

Slameto. (2013). Belajar dan Faktor-faktor Yang Mempengaruhi. Jakarta: Rineka Cipta.

Uno, B. (2014). Teori Motivasi dan Pengukurannya. Jakarta: Bumi Aksara. 